\title{
Analisis Pengendalian Puncak Banjir Menggunakan Kolam Retensi di DAS Batang Air Dingin Kota Padang
}

\author{
Analysis of Peak Discharge Control with Retention Ponds \\ At Batang Air Dingin Watershed Padang City
}

\author{
Fajri Ramadhan, Yola Amelia, Revalin Herdianto \& Elvi Roza Syofyan \\ Jurusan Teknik Sipil Politeknik Negeri Padang Kampus Limau Manis Padang 25163 \\ Telp. 0751-72590 Fax. 0751-72576 Email : fajri.jambak.7198@ gmail.com, \\ yolaamelia234@gmail.com, revalin.herdianto@gmail.com, syofyan_er@yahoo.co.id
}

\begin{abstract}
Batang Air Dingin Watershed is one of the watersheds in Padang City which is located at 00 50'12,5" to $00^{\circ} 50$ '22,5" South Latitude and $100^{\circ} 23$ '35,85" to 100'22'42,84" East Longitude has changed its function. Land in the area around the river flow results in greater surface runoff, which has the potential to cause erosion. Runoff that occurs in Batang Air Dingin Watershed area causes the river to shrink during the dry season causing the local residents' wells to be drought, while in the rainy season the river discharge value used is obtained. Through the calculation of the hydrograps discharge using the HSS Nakayasu and HEC-HMS methods whose values are validated by the field flood discharge. Hydraulic modelling using HEC-RAS software with discharge from HSS Nakayasu method. The retention pond plan is based on the amount of runoff that cannot be accommodated by the original storage capacity of Batang Air Dingin Watershed during 100 year return period was 1212, $94 \mathrm{~m}^{3} /$ second with large river storage capacity is $1205,317 \mathrm{~m}^{3} / \mathrm{second}$. The debit that can be deducted by making a retention pond is $30,5 \%$.
\end{abstract}

Keywords: Flood, HEC-HMS, HEC-RAS, Retention ponds

\section{PENDAHULUAN}

DAS adalah suatu wilayah yang merupakan satu kesatuan dengan sungai dan anak-anak sungainya, yang berfungsi menampung, menyimpan, dan mengalirkan air yang berasal dari curah hujan ke danau atau ke laut secara alami, yang batas darat merupakan pemisah topografi dan batas di laut sampai dengan daerah pengairan yang masih terpengaruh aktivitas daratan. Kriteria sebuah DAS dikatakan sehat apabila DAS menyediakan unsur hara bagi tumbuh-tumbuhan, menyediakan sumber makanan bagi manusia dan hewan, menyediakan air minum yang sehat bagi manusia dan makhluk lainnya, serta menyediakan tempat untuk berbagai aktivitas manusia dan hewan. Beberapa aktivitas DAS bisa menguntungkan kepada sebagian kawasan DAS, juga bisa merugikan. Aktifitas yang dilakukan di sekitar daerah aliran seperti pemanfaatan lahan yang tidak sesuai fungsinya mengakibatkan DAS Batang Air Dingin tidak mampu menampung dan menyimpan air hujan.

DAS Batang Air Dingin yang terletak pada $0^{0} 50^{\prime} 12,5^{\prime \prime}$ sampai dengan $0^{0} 50$ '22,52" Lintang Selatan dan $100^{\circ} 23^{\prime} 35,85^{\prime}$ ' sampai dengan $100^{0} 22^{\prime} 42,84$ " Bujur Timur mengalami alih fungsi lahan di daerah sekitar aliran sungai mengakibatkan limpasan permukaan semakin besar sehingga berpotensi menyebabkan erosi. Limpasan yang terjadi di daerah DAS Batang Air Dingin mengakibatkan sungai mengalami penyusutan selama musim kemarau menyebabkan sumur-sumur warga sekitar mengalami kekeringan, sedangkan pada musim penghujan debit sungai mengalami peningkatan dan seringkali menyebabkan banjir. Banjir yang terjadi pada tahun 2016 bahkan menyebabkan bendung yang terletak di sungai utama DAS Batang Air Dingin mengalami kerusakan parah. Sebagai upaya konservasi karena sungai 
Batang Air Dingin tidak mampu menahan air adalah dengan membuat kolam retensi. Kolam retensi memiliki prinsip kerja menahan air jika debit sungai mengalami peningkatan dan air yang tertahan tentu akan menyerap kedalam tanah dan mampu menaikkan elevasi muka air tanah.

Tujuan penelitian ini adalah untuk menganalisis besar limpasan permukaan yang dapat dikurangi dengan merencanakan kolam retensi di DAS Batang Air Dingin.

\section{Limpasan Permukaan (Run-off)}

Limpasan Permukaan atau Runoff merupakan air hujan yang jatuh ke bumi dan tidak terserap oleh tanah. Besar limpasan permukaan tergantung pada beberapa faktor seperti jenis tanah, komponen penyusun tanah sehingga ada potensi limpasan tinggi, sedang, lambat, hingga rendah. Limpasan permukaan terdiri atas aliran permukaan (direct runoff), aliran antara (interflow), dan aliran air tanah (baseflow).

Perubahan tata guna lahan mempengaruhi besar laju infiltrasi dan limpasan permukaan. Limpasan permukaan yang terjadi dapat menyebabkan erosi. Hidrograf limpasan langsung atau limpasan permukaan dihasilkan oleh hujan satuan berupa hidrograf satuan. Mengatasi masalah limpasan merupakan salah satu upaya yang dapat dilakukan sebagai usaha pengurangan debit puncak yang terjadi di sungai pada saat terjadi hujan.

\section{Kolam Retensi}

Kolam retensi adalah suatu bak atau kolam yang dapat menampung atau meresapkan air sementara yang terdapat didalamnya menurut Andayani, Djohan, dan Airlangga (2017) dalam (Zevri, 2019). Kolam retensi dibagi menjadi 2 macam tergantung dari bahan pelapis dinding dan dasar kolam, yaitu kolam alami dan kolam buatan. Pembangunan kolam retensi secara konsep dan prinsip yang digunakan yaitu tersedianya lahan yang cukup karena secara parsial berada di luar alur sungai dan tidak mengganggu sistem aliran sungai yang ada (Zevri, 2019). Prinsip kerja kolam retensi yaitu kolam akan menampung sementara air yang masuk melalui aliran permukaan maupun karena debit sungai mengalami peningkatan. Air tetap berada di dalam kolam untuk memperlama ketersediaan air sebagai upaya menghindari kekeringan. Kolam retensi dijadikan sebagai upaya untuk pelestarian air di dalam tanah dengan menahan air lebih lama sehingga dapat menaikkan muka air tanah dan untuk mengurangi limpasan permukaan (run off).

\section{Analisa Hidrologi}

Analisa hidrologi digunakan untuk memperkirakan besar banjir yang ditimbulkan oleh hujan, sehingga hasil besaran banjir tersebut bisa digunakan untuk merencanakan bangunan-bangunan sebagai pengendali banjir. Parameter yang berpengaruh pada perhitungan hidrologi seperti kondisi lahan (daerah aliran sungai) seperti jenis tanah, tata guna lahan, kemiringan lahan, dan lain sebagainya. Menghitung perencanaan hujan kawasan dengan menggunakan metoda Rata-Rata Aljabar, metoda Polygon Thiessen, dan metoda Isohiet. Analisis Distribusi Probabilitas Hujan dihitung menggunakan metode Normal, Log Normal, Gumbel dan Log Pearson Type III dan diuji probabilitas dengan metoda Chi-Kuadrat dan SmirnovKolmogorov. Analisis curah hujan dihubungkan dengan kejadian dan lamanya (durasi) hujan turun dengan metoda Mononobe. Menghitung debit rencana banjir menggunakan metode Rasional Modifikasi, Melchior, dan HSS Nakayasu.

\section{HEC-HMS}

HEC-HMS (Hydrologic Engineering Center-Hydrologic Modelling System) diciptakan oleh US. Army Corps. Of Engineers berbasis Graphical User Interface (GUI) (Syahputra, 2015). Menurut Pitocchi dan Mozalli (2001) model hidrologi dengan program HEC- 
HMS dirancang untuk menstimulasikan proses hujan-limpasan dari sistem aliran. Program ini dirancang agar dapat diaplikasikan dalam luasan tertentu untuk mempresentasikan proses hidrologi DAS (Syahputra, 2015).

\section{Analisa Hidraulika}

Nilai unsur-unsur aliran di saluran atau sungai, seperti kedalaman, kecepatan, dan debit bersifat steady pada saluan buatan dan tidak tetap atau selalu berubah ditinjau dari segi waktu dan tempat (unsteady and non uniform flow, aliran tidak steady dan tidak seragam). Beberapa faktor yang menyebabkan kondisi aliran seperti itu antara lain:

- Perubahan kemiringan memanjang dasar, perubahan penampang melintang, perubahan trase, dan pertemuan atau percabangan sungai.

- Adanya konstruksi bangunan, seperti pilar jembatan, bendung, bendungan, krib, dan sudetan.

- Adanya aliran samping (baik pengurangan maupun penambahan aliran), dan pengaruh pasang surut.

Analisa hidraulika untuk menghitung kapasitas tampungan sungai eksisting Batang Air Dingin menggunakan rumus manning dengan saluran berbentuk trapesium.

\section{HEC-RAS}

Software HEC-RAS merupakan program aplikasi yang dibuat oleh Hydrologyc Engineering Center (HEC) satu divisi di dalam Institute for Water Resources (IWR), di bawah US. Army Corps. Of Engineers (USACE). HEC-RAS merupakan model satu dimensi aliran permanen maupun tak permanen (steady and unsteady one-dimensional flow model). HEC-RAS memiliki empat komponen model satu dimensi, yaitu (1) hitungan profil muka air aliran permanen, (2) simulasi aliran tak permanen, (3) hitungan transport sedimen, dan (4) hitungan kualitas (temperature) air (Barokah dan Purwantoro, 2014).

\section{METODOLOGI}

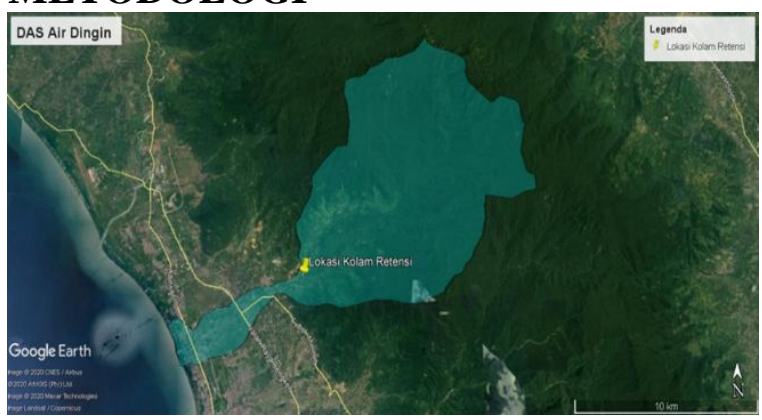

Gambar 1. Peta DAS Batang Air Dingin

Penelitian dilakukan dengan menggunakan metode survei yaitu pengumpulan data sekunder dan data primer antara lain sebagai berikut:

- Peta penggunaan lahan 2012 dari PU Kota Padang.

- Kondisi batas (boundary condition) hulu dan hilir sungai dari hasil wawancara langsung dengan masyarakat di lapangan.

- Data curah hujan harian Stasiun Koto Tuo dan Stasiun Gunung Nago dari tahun 2006 - 2019 dari BWS V Sumatera /PSDA.

- Profil melintang dan profil memanjang Sungai Batang Air Dingin dari Balai Wilayah Sungai Sumatera V.

\section{Analisis data curah hujan}

Analisa hidrologi digunakan untuk memperkirakan besar banjir yang ditimbulkan oleh hujan, sehingga hasil besaran banjir tersebut bisa digunakan untuk merencanakan bangunan-bangunan sebagai pengendali banjir. Parameter yang berpengaruh pada perhitungan hidrologi seperti kondisi lahan (daerah aliran sungai) seperti jenis tanah, tata guna lahan, kemiringan lahan, dan lain sebagainya. Menghitung perencanaan hujan kawasan dengan menggunakan metoda Rata-Rata Aljabar, metoda Polygon Thiessen, dan metoda Isohiet. Analisis Distribusi Probabilitas Hujan dihitung menggunakan 
metode Normal, Log Normal, Gumbel dan Log Pearson Type III dan diuji probabilitas dengan metoda Chi-Kuadrat dan SmirnovKolmogorov. Analisis curah hujan dihubungkan dengan kejadian dan lamanya (durasi) hujan turun dengan metoda Mononobe.

\section{Debit rencana banjir}

Data yang diperlukan dalam perencanaan bangunan air seperti data karakteristik daerah pengaliran (data topografi dan data tata guna lahan), data curah hujan yang selanjutnya digunakan untuk perhitungan debit rencana menggunakan metoda Rasional modifikasi, Melchior dan HSS Nakayasu. Debit rencana banjir juga dihitung menggunakan software HEC-HMS yang hasil kedua perhitungan dibandingkan dengan debit banjir lapangan.

\section{Analisis hidraulika}

Nilai unsur-unsur aliran di saluran atau sungai, seperti kedalaman, kecepatan, dan debit umumnya bersifat tidak tetap atau selalu berubah ditinjau dari segi waktu dan tempat (unsteady and nonuniform flow, aliran tidak steady dan tidak seragam).

a. Dimensi penampang saluran

Analisis hidraulika dilakukan untuk menghitung kapasitas tampungan yang dapat ditampung oleh penampang yang telah direncanakan. Analisis hidraulika dapat memberikan informasi debit yang dapat ditampung penampang sungai eksisting juga volume tampungan kolam retensi yang direncanakan.

b. Analisa profil muka air menggunakan software HEC-RAS

Langkah-langkah pemodelan dengan program aplikasi HEC-RAS menurut Noor dan Utomo (2013) ada beberapa langkah, yaitu (1) pembuatan file project, (2) peniruan geometri saluran dengan memasukkan data geometri saluran, (3) peniruan hidrolika saluran dengan memasukkan data aliran dan syarat batas, (4) hitungan hidraulika aliran dengan mengeksekusi program, dan (5) presentasi hasil hitungan dengan menampilkan hasil di layer atau mencetaknya.

c. Dimesi kolam retensi

Kolam retensi di desain berdasarkan kemampuan sungai dalam menampung debit air yang ada sehingga volume tampungan dari kolam retensi harus mampu menampung air yang melimpas. Untuk menghitung debit kolam retensi digunakan rumus:

$\mathrm{Q}_{\text {kolam retensi }}=\mathrm{Q}_{\text {banjir rencana }}-\mathrm{Q}_{\text {tampungan saluran }}$ Persamaan untuk menghitung volume kolam retensi adalah:

Volume kolam retensi $=\mathrm{Q}_{\text {kolam retensi }} \mathrm{x}$ ( $\left.t_{\text {normal - }} t_{\text {banjir }}\right)$

Dimensi kolam retensi dapat dihitung menggunakan persamaan sebagai berikut:

Dimensi kolam retensi $=A \times T$

Dimana:

$\mathrm{t}_{\text {normal }}=$ waktu normal $(\mathrm{jam})$

$\mathrm{t}_{\text {awal banjir }} \quad=$ waktu awal banjir (jam)

A $\quad=$ luas kolam retensi $\left(\mathrm{m}^{2}\right)$

$\mathrm{T}=$ kedalaman atau tinggi

kolam retensi $(\mathrm{m})$

\section{Analisis permeabilitas tanah}

Permeabilitas didefinisikan sebagai sifat bahan berpori yang memungkinkan aliran rembesan dari cairan yang berupa air atau minyak mengalir lewat rongga pori. Permeabilitas tanah berarti sifat tanah yang mengalirkan air melalui pori tanah. Air di dalam tanah mengalir dari energi rendah ke energi yang lebih tinggi. Secara teoritis, setiap tanah memiliki rongga pori, namun permeabilitas tanah lebih kurang dimaksudkan untuk tanah yang memiliki kemampuan meloloskan air. Sedangkan tanah yang memiliki kemampuan sangat kecil dalam meloloskan air disebut kedap air. 
Diagram Alir Penelitian

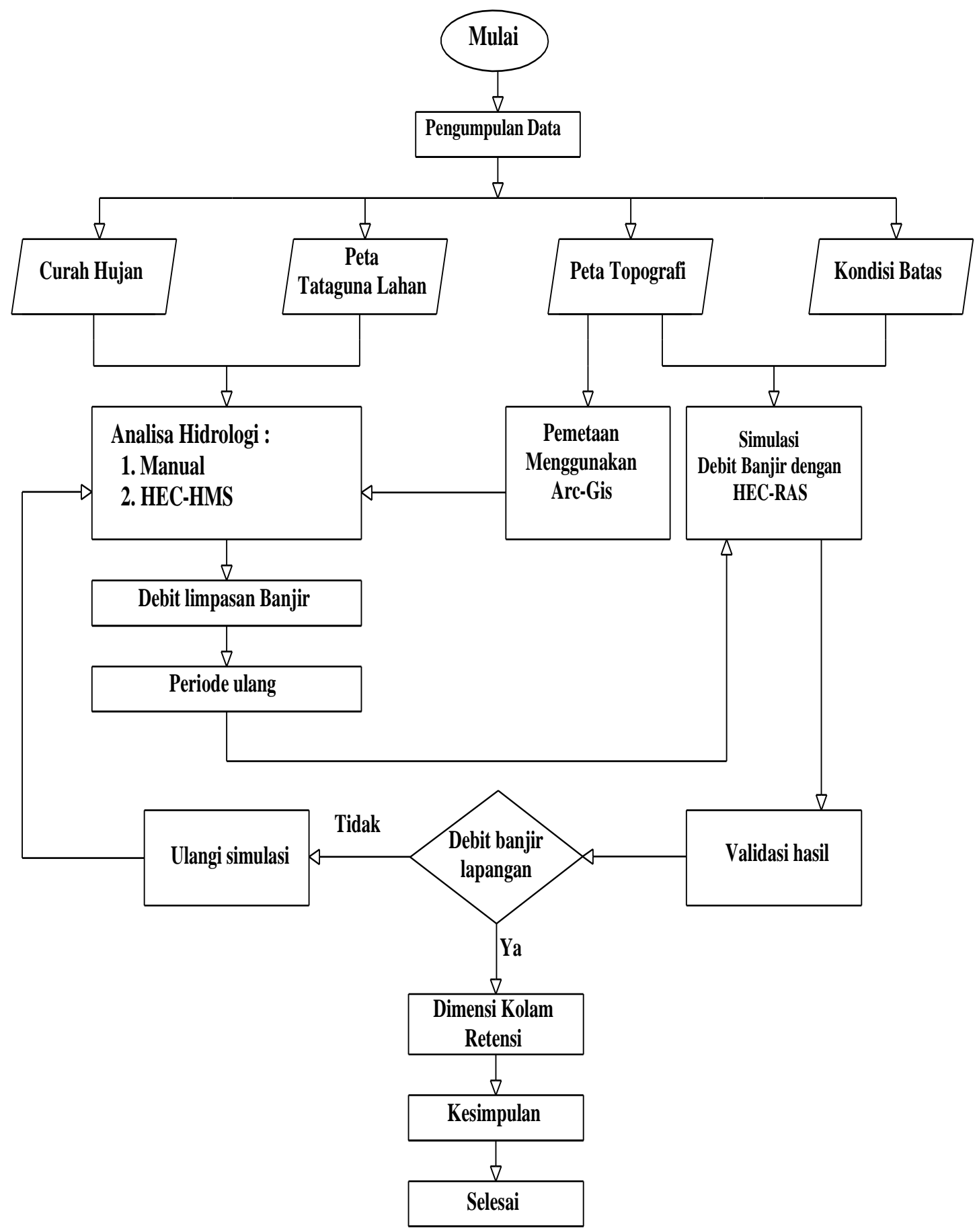

Gambar 2. Diagram Alir Penelitian 


\section{HASIL DAN PEMBAHASAN}

\section{Analisis debit debit rencana banjir}

Tabel 1. Rekapitulasi Perhitungan Debit Rencana

\begin{tabular}{|c|c|c|c|c|c|}
\hline \multirow{2}{*}{ No } & \multirow{2}{*}{ Periode Ulang (T) } & \multicolumn{3}{|c|}{ Debit Rencana $\left(\mathbf{Q}_{\mathbf{T}}\right)$} & \multirow{2}{*}{ Debit Tampungan } \\
\cline { 3 - 5 } & & Rasional Modifikasi & Melchior & HSS Nakayasu & \\
\hline 1 & 2 & 594.35 & 476.20 & 642.96 & \\
\hline 2 & 5 & 740.79 & 593.53 & 801.39 & \\
\hline 3 & 10 & 832.89 & 667.32 & 901.02 & \multirow{2}{*}{1205.317} \\
\hline 4 & 20 & 921.22 & 738.09 & 996.57 & \\
\hline 5 & 25 & 940.28 & 753.36 & 1017.19 & \\
\hline 6 & 50 & 1035.55 & 829.70 & 1120.25 & \\
\hline 7 & 100 & 1121.23 & 898.34 & 1212.94 & \\
\hline
\end{tabular}

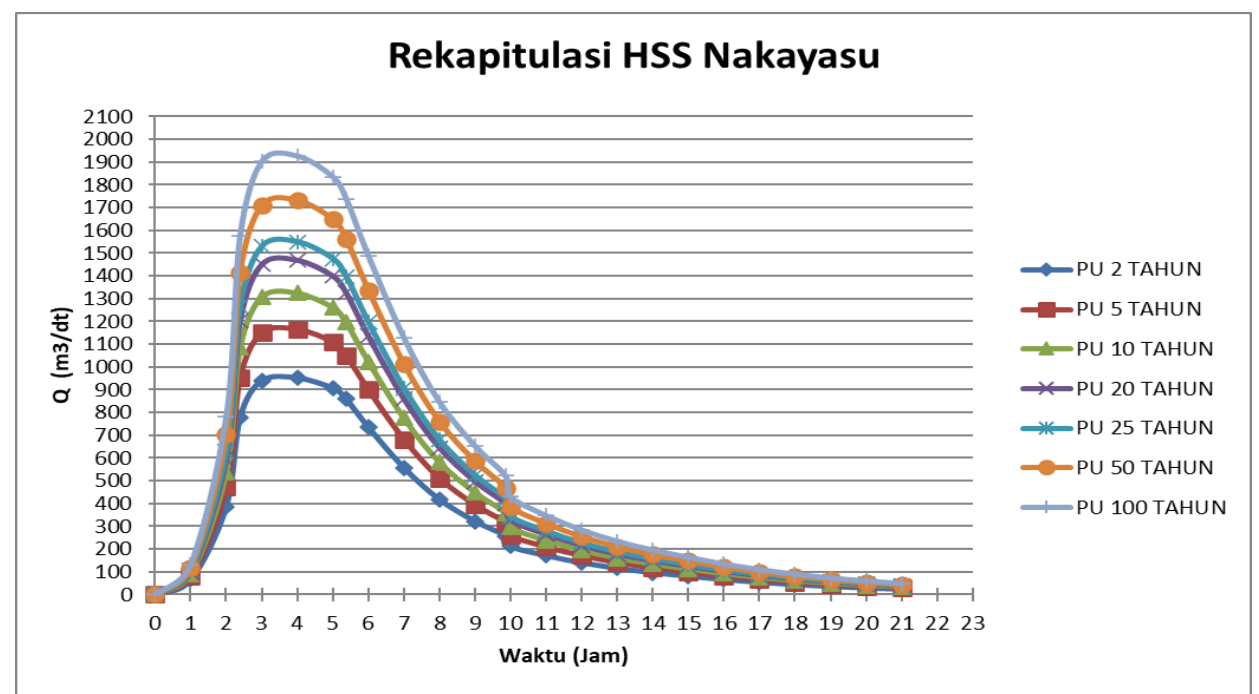

Gambar 3. Hidrograf Banjir Metode HSS Nakayasu

\section{Simulasi debit banjir dengan software HEC-HMS}

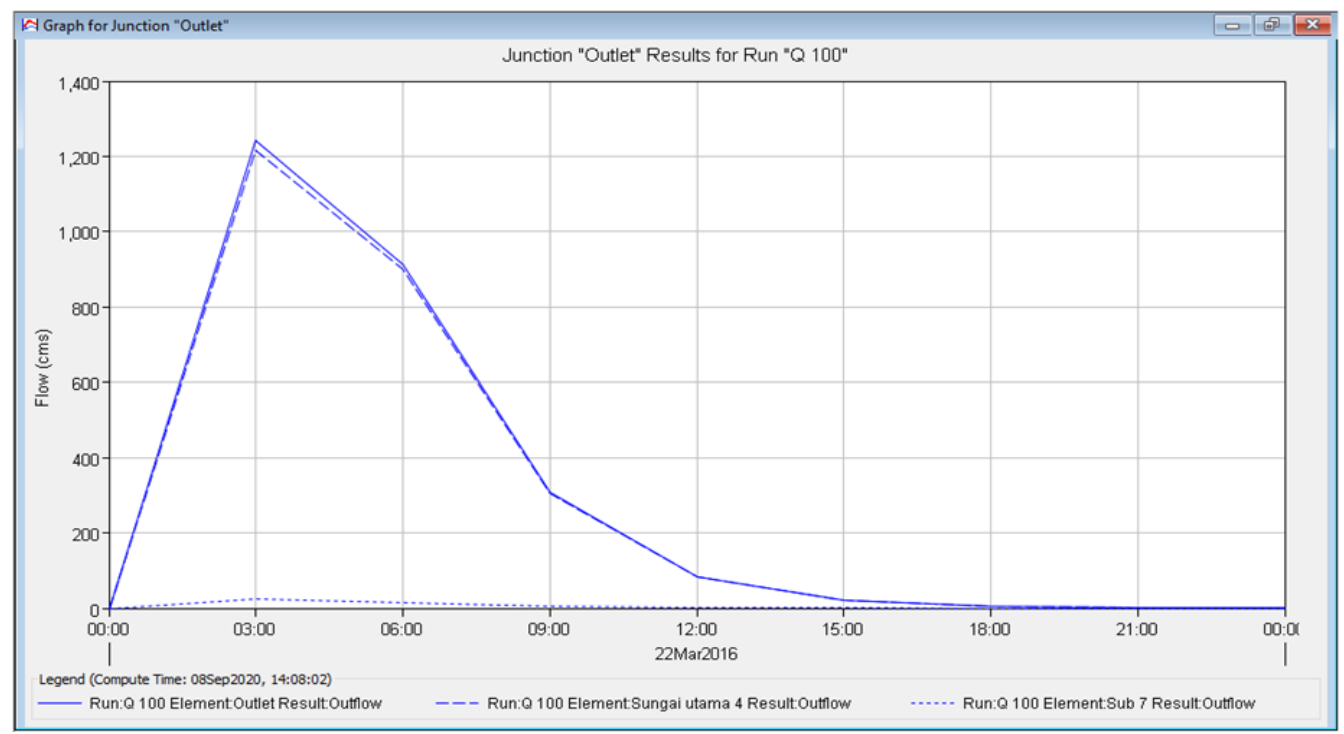

Gambar 4. Hidrograf Banjir Metode SCS-CN HEC-HMS 


\section{Kapasitas tampungan sungai}

Debit banjir aktual yang ada dilapangan saat banjir adalah sebesar $649,96 \mathrm{~m}^{3} / \mathrm{dt}$ mendekati nilai debit banjir rencana HSS Nakayasu 2 tahun 642,96 $\mathrm{m}^{3} / \mathrm{dt}$. Lalu diambil debit banjir rencana sepuluh tahun pada metode HSS Nakayasu sebesar $1212,94 \mathrm{~m}^{3} / \mathrm{dt}$.

\section{Dimensi penampang saluran}

Tabel 2. Perhitungan Debit Banjir Sungai Eksisting

\begin{tabular}{|c|c|c|}
\hline Lebar Sungai & $\mathrm{b}$ & 50.600 \\
\hline Tinggi Saluran & $\mathrm{h}$ & 4.2 \\
\hline Luas Penampang & $\mathrm{A}$ & 228.096 \\
\hline Kemiringan dinding saluran & $\mathrm{M}$ & 1 \\
\hline angka kekasaran manning & $\mathrm{n}$ & 0.045 \\
\hline Kemiringan saluran & $\mathrm{I}$ & 0.010038 \\
\hline Keliling Penampang Basah Saluran & $\mathrm{P}$ & 62.380 \\
\hline Jari-Jari hidrolis & $\mathrm{R}$ & 3.657 \\
\hline Kecepatan Aliran & $\mathrm{V}$ & 5.284 \\
\hline Debit tampungan & $\mathrm{Q}$ & 1205.317 \\
\hline
\end{tabular}

\section{Simulasi profil muka air dengan HEC- RAS}

Tabel 3. Profil Muka Air dengan program $H E C-R A S$

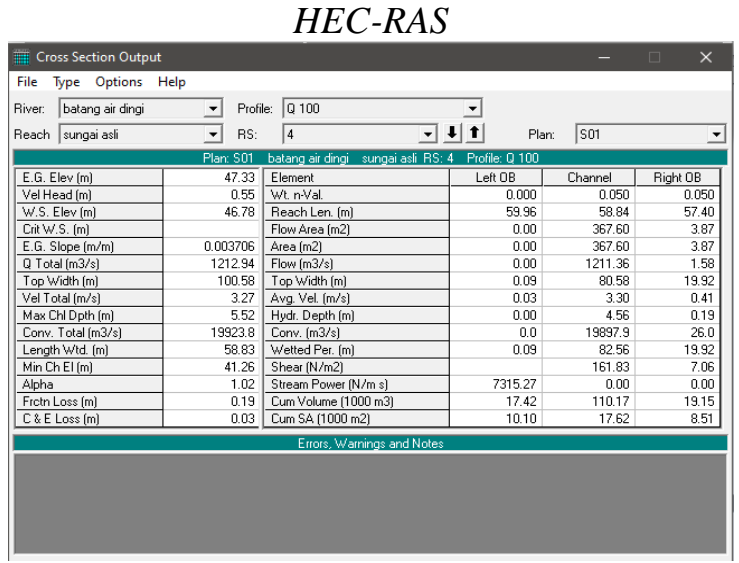

\section{Kolam Retensi}

Kolam retensi direncanakan di daerah Lubuk Minturun yang terletak pada DAS Air Dingin, tepatnya berada pada sub DAS Air Dingin Hulu. Lokasi yang direncanakan berada terletak di sepertiga dari panjang sungai utama.

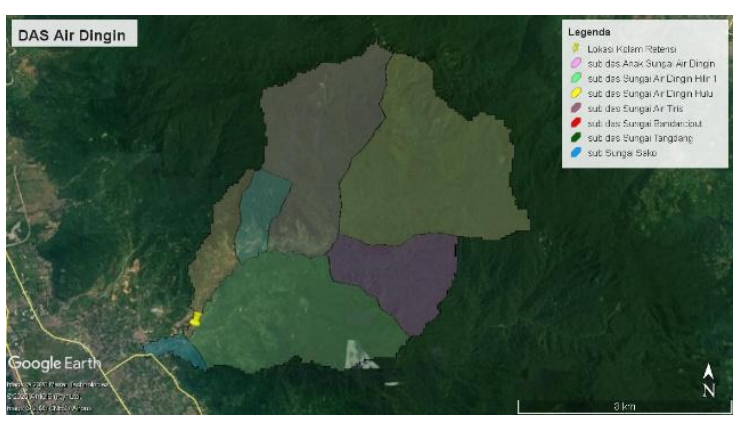

Gambar 5. Lokasi Kolam Retensi

Untuk perencanaan kolam retensi di rencanakan sebagai berikut:

$$
\begin{aligned}
Q_{\text {kolam }} & =Q_{\text {hujan rencana }}-Q_{\text {tampungan eksisting }} \\
& =1212,940-1205,317 \mathrm{~m}^{3} / \mathrm{dtk} \\
& =7,623 \mathrm{~m}^{3} / \mathrm{dtk}
\end{aligned}
$$

Volume yang harus ditampung kolam retensi dalam hujan 2,3 jam adalah sebagai berikut:

$$
\begin{aligned}
\text { Volume }_{\text {kolam }} & =\mathrm{Q} \text { x waktu puncak } \\
& =7,623 \mathrm{~m}^{3} / \mathrm{dtk} \times 2,389 \mathrm{jam}
\end{aligned}
$$$$
=65560,849 \mathrm{~m}^{3}
$$

Jika direncanakan dimensi sebagai berikut:

Panjang kolam retensi $\quad=100 \mathrm{~m}$

Lebar kolam retensi $\quad=100 \mathrm{~m}$

Kedalaman kolam retensi $\quad=2 \mathrm{~m}$

Dengan demikian didapat volume yang dapat ditampung kolam retensi sebagai berikut:

$$
\begin{aligned}
\mathrm{V} & =\mathrm{P} \times \mathrm{L} \times \mathrm{T} \\
& =(100 \times 100 \times 2) \mathrm{m} \\
& =20.000 \mathrm{~m}^{3} \\
\mathrm{Q} & =\mathrm{V} / \mathrm{t} \\
& =20.000 / 2,389 \mathrm{jam} \\
& =2,325 \mathrm{~m}^{3} / \mathrm{dtk}
\end{aligned}
$$

\section{Koefisien permeabilitas tanah}

Data yang dibutuhkan untuk nilai permeabilitas tanah didapat dari hasil penelitian terdahulu yang berlokasi di DAS Batang Air Dingin. Penelitian yang digunakan adalah penelitian oleh Rendra Aulia Pratama dan Rusli HAR yaitu pada jurnal Kajian Laju Infiltrasi pada DAS Air Dingin Kota Padang Ditinjau dari Perbedaan Litologi Batuan, Kemiringan Lahan, Jenis Tutupan Lahan, dan Sifat Fisik Tanah tahun 2018. Berdasarkan 16 data pengukuran, diperoleh nilai rata-rata laju infiltrasi sebesar $0,10851 \mathrm{~cm} /$ menit. 
Maka berdasarkan klasifikasi Hutasoit, laju infiltrasi pada DAS Air Dingin termasuk Zona VI/D yang artinya klasifikasi daerah resapan sangat rendah $(0,1-0,2$ $\mathrm{cm} /$ menit).

Menurut Florince, Arifaini, dan Adha (2015) untuk menghitung volume teresap dalam kolam retensi adalah sebagai berikut:

$$
\begin{aligned}
\mathrm{V}_{\text {teresap }}= & \text { Luas Kolam Retensi } \times \text { Kapasitas } \\
& \text { Infiltrasi } \times 0,01 \times \mathrm{t} \\
= & 10000 \mathrm{~m}^{2} \times 0,0010851 \mathrm{~m} / \mathrm{jam} \times \\
& 0,01 \times 2,389 \mathrm{jam}
\end{aligned}
$$

\section{SIMPULAN}

Besar hujan rencana Sungai Batang Air Dingin periode ulang 100 tahun adalah sebesar 302,67 mm dihitung menggunakan metode Distribusi Curah Hujan Gumbel. Besar limpasan permukaan periode ulang 100 tahun sebesar $1212,940 \mathrm{~m}^{3} / \mathrm{dtk}$ dihitung menggunakan metode HSS Nakayasu. Kapasitas tampungan alamiah Sungai Batang Air Dingin adalah sebesar $1205,317 \mathrm{~m}^{3} / \mathrm{dtk}$. Volume yang harus ditampung kolam retensi sebesar

\section{DAFTAR PUSTAKA}

[1] Barokah, I., \& Purwantoro, D. (2014). Pengaruh variasi debit aliran terhadap gerusan maksimal di bangunan jembatan dengan menggunakan program HEC-RAS. Jurnal Inersia,10(2), 175-184.

[2] Florince., Arifaini, N., \& Adha, I. (2015). Studi kolam retensi sebagai upaya Pengendalian banjir sungai Wai Simpur Kelurahan Palapa Kecamatan Tanjung Karang Pusat. JRSDD,3(3),507-520.

[3] Harmani, E., \& Soemantoro, M. (2015). Kolam retensi sebagai alternatif pengendali banjir. Jurnal Teknik Sipil,1(1), 71-80.

$$
=0,259 \mathrm{~m}^{3}
$$

Maka, kapasitas satu kolam retensi terdiri atas volume kolam sendiri yaitu sebesar $20.000 \mathrm{~m}^{3}$ ditambah dengan volume yang teresap tanah yaitu sebesar $0,259 \mathrm{~m}^{3}$, sehingga total yang dapat ditampung kolam retensi adalah sebesar $20000,259 \mathrm{~m}^{3}$. Dari volume yang harus ditampung kolam retensi yaitu sebesar $65560,849 \mathrm{~m}^{3}$, dibutuhkan sekitar 4 buah kolam retensi.

$65560,849 \mathrm{~m}^{3}$ dari hasil kali antara debit yang tidak dapat ditampung oleh sungai dengan waktu puncak banjir terjadi. Dengan satu buah kolam retensi didapat pengurangan volume sebesar 20.000,259 $\mathrm{m}^{3}$, dengan debit puncak banjir sebesar $7,62 \mathrm{~m}^{3} / \mathrm{dtk}$ dan akibat kolam retensi berkurang sebesar $2,325 \mathrm{~m}^{3} / \mathrm{dtk}$. Maka, besar pengurangan debit akibat adanya kolam retensi adalah sebesar $30,5 \%$.

[4] Herdianto, R., Syofyan, E. R., \& Aguskamar. (2013). Pemanfaatan Informasi Topografi dan Indeks Vegetasi untuk Studi Dinamika Proses Hidrologi Daerah Aliran. Jurnal Ilmiah. POLI REKAYASA. Volume 8 Nomor 2, April 2013. ISSN : 1858-3709.

[5] Herdianto, R., Istijono, B., Syofyan, E. R., \& Dalrino.(2018). Investigation of Pangkalan Floods: Possible Reasons and Future Directions. International Journal on Advanced Science, Engineering and Information Technology, Vol.8 (2018) No. 6 , pp. 2510- 2515.

[6] Herdianto, R., Syofyan, E. R., Hanwar, S., Istijono, B., \& Dalrino. (2017). The Investigation of 1997 
and 2015 El Nino Events in West Sumatera, Indonesia. International Journal on Advanced Science, Engineering and Information Technology, Vol. 7 (2017) No. 2, pp. 418-423.

[7] Jansen, D., Jansen, T., \& Hendratta, L. A. (2017). Kajian efektifitas pengendalian banjir di DAS Torosik. Jurnal Ilmiah Media Engineering,7(3), 936-940.

[8] Istiarto. (2014). Simulasi aliran 1dimensi dengan bantuan paket program hidrodinamika HEC-RAS. Modul Latihan. Yogyakarta.

[9] Kamiana, I. K. (2011). Teknik perhitungan debit rencana bangunan air. Graha Ilmu: Yogyakarta.

[10] Marko, K., \& Zulkarnain, F. (2018). Pemodelan debit banjir sehubungan dengan prediksi perubahan tutupan lahan di daerah aliran $\mathrm{Ci}$ Leungsi hulu menggunakan HEC-HMS. Jurnal Geografi Lingkungan Topik, 2(1), 26-37.

[11] Munajad, Rifai. (2015). Kajian hujan-aliran menggunakan model HEC-HMS di sub daerah aliran Sungai Wuryantoro Wonogiri, Jawa Tengah. 4(1), 150-157.

[12] Natakusumah, D. K., Hatmoko, W., \& Harlan, D. (2011). Prosedur umum perhitungan hidrograf satuan sintesis dengan cara ITB dan beberapa contoh penerapannya. Jurnal Teoritis dan Terapan Bidang Rekayasa Sipil,18(3), 251-291.

[13] Noor, M. A., \& Utomo, B. (2013). Studi kapasitas sungai riam kiwa menggunakan HEC-RAS 4.1.0. Jurnal Info Teknik,14(1), 81-91.I

[14] Pratama, R. A., \& HAR, R. (2018). Kajian laju infiltrasi pada DAS Air
Dingin Kota Padang ditinjau dari perbedaan litologi batuan, kemiringan lahan, jenis tutupan lahan, dan sifat fisik tanah. Jurnal Bina Tambang,3(4), 1423-1433.

[15] Putra, A., Triyatno, Hermon, D., \& Syarief, A. (2017). Prediksi erosi lahan pada DAS Air Dingin bagian hulu di kota Padang. Spatial Wahana Komunikasi dan Sistem Informasi, 17(2), 43-52.

[16] Sitanggang, G. E., Suprayogi, I., \& Trimaijon. (2014). Pemodelan hujan debit pada sub daerah aliran sungai menggunakan program bantu HECHMS (Studi kasus pada kanal Duri). Jurnal Online Mahasiswa,1(1).

[17] Syahputra, I. (2015). Kajian hidrologi dan analisa kapasitas tampang Sungai Krueng Langsa berbasis HEC-HMS dan HEC-RAS. Jurnal Teknik Sipil Unaya,1(1), 1528.

[18] Syofyan. E. R, Saidi, A., Istijono, B., \& Herdianto, R. (2017). Model Hidrograf Akibat Perubahan Tataguna Lahan DAS Batang Kuranji (Studi Kasus Sub DAS Danau Limau Manis). POLI REKAYASA Volume 13, Nomor 1, Oktober 2017.

[19] Syofyan. E. R, Saidi, A., Istijono, B., \& Herdianto, R. (2016). Kajian Model Hidrograf Akibat Perubahan Tataguna Lahan dengan Menggunakan Data Lapangan DAS Batang Air Dingin . POLI REKAYASA Volume 12, Nomor 1, Oktober 2016.

[20] Syofyan, E. R., Saidi, A., Istijono, B., Herdianto, R., (2018). The Hidrologic Impacts of Land Use Changes in the Middle and Upper 
Catchment. International Journal of Civil Engineering and Technology (IJCIET) 9 (11), 2018, pp. 997-1005.

[21] Syofyan, E. R., Saidi, A., Istijono, B., Herdianto, R., (2020). The Changes of Runoff with DEM Resolution. International Journal of Recent Technology and Engineering (IJRTE) ISSN: 2277-3878, Volume8 Issue-6, March 2020.

[22] Triatmojo, B. (2008). Hidrologi terapan. Yogyakarta: Beta Offset Yogyakarta.

[23] Yanti, N. R., Rusnam, \& Ekaputra, E. G. (2017). Analisis debit pada DAS Air Dingin menggunakan model SWAT. Jurnal Tekhnologi Pertanian Andalas,21(2), 127-137.1

[24] Wardhana, P. N. (2015). Analisis transpor sedimen Sungai Opak dengan menggunakan program HECRAS 4.1.0. Jurnal Teknisia,20(1), 22-31.

[25] Wigati, R., Sudarsono., \& Cahyani, I. D. (2016). Analisis banjir menggunakan software HEC-RAS 4.1 (Studi kasus sub DAS Cisimeut hilir HM 0+00 sampai dengan HM 69+00). Jurnal Fondasi,5(1), 13-23.

[26] Yudi, R. K., Nugroho, A. M., Darsono, S., \& Wulandari, D. A. (2017). Perencanaan sistem polder wilayah Semarang Timur. Jurnal Karya Teknik Sipil,6(2), 265-27.

[27] Zevri, A. (2019). Desain kolam retensi pada daerah aliran Sungai Bekala. Jurnal Rekayasa Sipil (JRSUNAND),15(2), 90-102. 